\title{
The Empirical Study of Expansive Learning of College Students Basing on the Expansive Teaching Experiment
}

\author{
Yue Liu \\ Changsha University of Science \& Technology \\ Changsha, China 410001
}

\author{
Wei Huang \\ Changsha University of Science \& Technology \\ Changsha, China 410001
}

\begin{abstract}
Basing on the expansive learning theory and the changing laboratory, the study designed and implemented the expansive teaching experiment to explore the application model of expansive learning in the field of courses in Chinese colleges. Then, it developed the learning scale of college students from four dimensions of autonomic knowledge expansion, multi-source information acquisition, multi-agent learning interaction and practice. In the end, it quantitatively tested the effectiveness of the application model. The results showed that the expansive teaching experiment promoted the individual expansive learning. The individuals with more preference for their own majors, educational promotion and professional qualification had significantly higher level of expansive learning. And the individuals who spent more time and energy on close-book exam had significantly lower level of expansive learning. The individuals with more preference for careers in their own majors had significantly higher level of tendency but insignificantly higher level of practice for expansive learning.
\end{abstract}

Keywords-expansive teaching experiment; expansive learning; application model; expansive learning scale

\section{INTRODUCTION}

Traditional courses generally examine the students' knowledge of the established experience and the vertical raise of established ability. And it inevitably has curing characteristics of knowledge and acquisition. Students may have no desire or practice to seek the various channels to make other multi-subject interaction in addition to the classroom and teachers. And then, they wouldn't explore and build new knowledge or skills in addition to the established ability. It isn't conducive to cultivating students' ability of autonomy, exploration, practice and cooperative learning. (J. Biggs et al [1]; Liu Hua [2]). Compared with the vertical way of teaching, classroom group discussions may be able to stimulate the students' desire to build new knowledge according to stimulate students' critical thinking. However, the subject of the group discussion is determined by the teacher in advance. In many years, Chinese students tend to

This work was supported by Hunan Provincial Natural Science Foundation of China (Grant No.2017JJ3329), Hunan Provincial Academic Degree \& Postgraduate Educational Reform Project of China (Grant No. JG2015B077) and Scientific Research Fund of Hunan Provincial Education Department (Grant No.17C0073) obtain the standard from the authority in examinationoriented education environment. The effect of conversion in the application environment is still controversial (Meng Xiangju [3]).

The expansive learning put forward by Y. Engstrom from Finland is a learning theory framework basing on the learning theory of third generation (Y. Engestrom et al, 1999 [4], 2010 [5]). Compared with the traditional learning model, the expansive learning theory regards learning as a dynamic relationship between individual and social contexts as well as the creation of new knowledge and new activities in the workplace. Especially, it puts emphasis on changing the existing practice and the reconstruction of new activities. And it mainly focuses on the learning process rather than knowledge transmission. The learning content isn't determined in advance. The purposes of learning aren't to establish knowledge or skills, but to build a new object and activity system (Wu Gang, etc., 2014 [6][7]; Zeng Wenjie et al., 2013 [8]). The use of the practice tool of expansive learning - the change laboratory (Wu Gang, 2013 [9]), which is not only as close as possible to but also independent from the place of practice, enables to intervene individual's learning process to observe project efficiency and team promotion in different fields. J. Virkkunen et al (2013 [10]) and Wu Gang (2013 [9]) have divided the distinction between the change laboratory and the traditional experiments into four points. (1) The intervention of the change laboratory is part of the learning activities. The participants and the intervenor face the uncertainty of the object. (2) The participants of the change laboratory are the subject of controlling the process. (3) The intervention of change laboratory is the formative intervention, and the purpose is to form a new conceptual framework. (4) The task of the intervenor of change laboratory is to promote the process of learning revolution. In short, the change laboratory is a practical form of the expansive learning theory, which provides a set of toolkits that apply the theory of expansive learning to the field of practice. It promotes the expansive learning of individual and organization to achieve innovation and the revolution of the organization and team through the formative intervention (A. Haapasaari, 2016 [11]). Not only the theory of expansive learning is in line with the opening principles of promoting students' selfconstructing knowledge, releasing the multiple intelligences 
of the student groups and improving the participation of the students, but also the practical tools - change laboratories provide new experimental tools for exploring new university courses in the Chinese context.

In view of this case, this study has designed and implemented expansive teaching experiments basing on expansive learning. It quantitatively evaluates the differences of the expansive learning of Chinese college students in the expansive teaching experiments and academic preferences with the experimental and empirical methods. The purpose of this paper is to explore the application base mode of expansive learning theory in the university teaching in China, and to seek ways to improve the autonomy, inquiry, cooperation and practical ability of Chinese college students by breaking "relying on authority" of Chinese college students.

\section{LITERATURE REVIEW}

In the West, the expansive learning theory and practice tools - change laboratories are widely used in learning guidance in banking, schools, libraries, public sector and other workplaces (Y. Engestrom et al, 2012 [12]). A. Pasanen et al (2005[13]) emphasizes the important role of formative intervention in promoting extended learning by tracking the work of investment managers in the banking. J. Haigh (2007 [14]) argues that the expansive learning theory provides good framework for studying the learning theory of university and practice. And it uses the framework to analyze the learning experiences of medical students in the simulated clinical field. M. Gustavsson (2009 [15]) conducts a twoyear observation and a follow-up interview of leaders and employees in Swiss public sectors. It finds that the public sectors with limited resources are possible to promote expansive learning through rational organization in the workplace. H. Kerosuo et al (2013) has analyzed the types and frequency of expansive learning activities in the library workplace according to the statistics of change laboratory. It believes that learning subjects have the potential of creative work. And it must give the opportunity to the learning subject to redesign its work activities [16]. In China, Wu Gang (2015) has created the base model which is suitable for China's local expansive learning and change laboratory for the first time [17]. Ma Xiangyuan (2016) tried to apply change laboratory to research project of the university and college[18]. Zhang Lihua (2014) and Zhang Baocheng (2017) explored the guiding significance of the expansive learning to teachers' self-professional learning [19][20]. To sum up, there is a large exploration space in application base model of the expansive learning in the China's national condition. Especially, in the Chinese university course (G. Anthony, 2014 [21]), the assessment of the effectiveness of the application base model remains qualitative and lacks rigorous quantitative assessment.

Different from the previous literatures, this study has designed university curriculum and expansive teaching experiments to explore the application base model of expansive learning in the field of the Chinese university curriculum basing on the theory of expansive learning and change laboratory. And then, it would control individual academic preferences and other factors in the previous study by setting the experimental group - control group. And it uses the scale to measure the willingness and practice of individual expansive learning. It has test the difference of the individual expansive learning in the expansion of teaching experiments and academic preferences. It quantitatively evaluates the effectiveness of the application base model.

\section{THE DESIGN AND IMPLEMENTATION OF EXPANSIVE TEACHING EXPERIMENTS}

\section{A. Experimental Subjects}

According to the theory of expansive learning, the learning process of students (participants) should not be monopolized by teachers (interventionists). With the development of learning activities, it has formed a new conceptual framework through the joint intervention of teachers and students. The task of the intervenor isn't to control all the experimental variables, but to stimulate and maintain the expansive revolution process (Wu Gang, 2015 [17]). However, some variables can't be properly controlled. It is difficult to separate the effect of experimental projects from the effect of other variables and precisely assess the effectiveness of change laboratory. For example, the heterogeneity of the participants and the experimental project can lead to the promotion of individual learning. In this study, it combines the traditional experiment with the method of change laboratory to set up the experimental group and the control group to test the factors beside the project.

It should take the third grade students of the second school of accounting as the experimental subjects. And it could take 1-4 classes among the nine classes as the control group. Also, it could take 5-9 classes as the experimental group. The courses, syllabus, teaching materials, teaching media, course time and teaching environment of two groups are the same. And then, it can control the professionals, educational levels, learning environment and other interference factors. It can choose management coursescorporate tax planning as a platform to perform the teaching experiment.

\section{B. Experimental Plan}

The purpose of expansive teaching experiment is to cultivate, enhance and assess the self-construction of students' knowledge. Teachers wouldn't provide specific research topics for students in advance. And the teachers would promote students to gradually clear specific research objects and research programs through discussion, collection, reading and sorting information. In this process, it develops the self-construction of expansive learning of the students. The conflict and contradictory arising from the different understandings of the research objectives and objects have promoted the development of the group program. And the results of the self-construction have been ultimately reflected in the students' program reports.

The experiment requires that it should take 5-8 people as a research group unit of the experimental group. And it could develop research topics related to their own curriculum. They would determine the main research framework of the subject through the focused discussion of the group. They 
could complete the project research with cooperation. Finally, it could show the research report. It would pass the content of the task and the manner of evaluation to the group in the first lesson. The group would have three-month theoretical course with the task. In the last eight hours, the group would present the subject and the research content in graduation thesis defenses. Teachers, practical experts and other groups would ask question on the contents of the statement.

\section{Intervention Mechanism}

It would take a long time to converge the experimental results of the change laboratory. Usually, it would take about 2 years. Theoretically, it is generated with the spontaneity and uncertainty during the expansive learning process. And it can be overcome by formative intervention. (B. Berry, 2013 [22]). Therefore, it has set double intervention subject of the leader of team and the teacher to guide research object and the program of the experimental group in this experiment. Each team leader needs to organize discussion, record, coordinate and communicate members' opinions. And they also should clear research direction and division of labor and other tasks. Sometimes, they would explore the progress of the group and communicate with teachers. Teachers should achieve intervention through a series of rules. (1) It should take the internship opportunities as the incentive measures to stimulate the winning team members. (2) It should set the formative assessment method. The group research results have accounted for $40 \%$ of the total score. The usual results and final examination results have accounted for $30 \%$ and $40 \%$. (3) It has showed the division of work to prevent "free ride". (4) It should take the dynamic intervention of the teachers. The teacher could guide the students. However, they can't replace the group to confirm "high quality" subject. For example, the group members would set the topic of "research on tax preferential policy". Teachers would suggest that the scope of the study is too large. According to accumulation and discussion, the members of the group have adjusted the topic to "preferential tax policy on energy saving and emission reduction". Teachers would suggest to combine preferential tax policy on energy saving and emission reduction with "two-oriented society" background. (5) The evaluations of both teachers and practical experts should be considered. The practical experts could be invited to listen to the reports and make evaluation. It has shown expansive learning process of the group under the intervention mechanism in the figure.

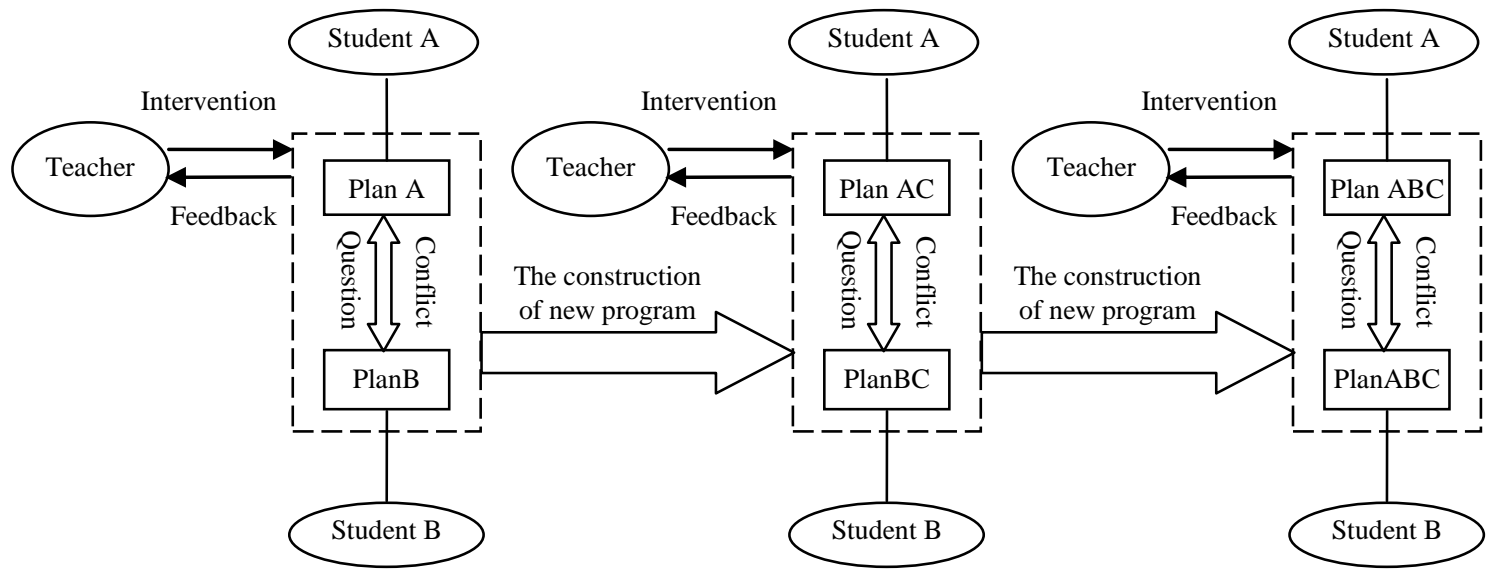

Fig. 1. The Expansive Learning Process of the Group in the Experiment.

\section{Experimental Feedback}

According to the observation and the interview, this study finds that the expansive teaching experiments effectively change the traditional curriculum learning mode of college students. It could stimulate autonomy, critical and innovative learning of the experimental object. To a certain extent, it could break through the dilemma of relying on authority in traditional curriculum of college students. It has these main findings. (1) In expansive teaching experiment, students wouldn't accept the transmission of knowledge symbol of "teachers' authority" passively. And the students would explore new unknown areas with teachers. During the period of working arrangement to the final presentation of the group, the students in the experimental group have initiated and overturned the feasibility, novelty, social value, analytical methods and solutions of the project. For example, the project methods of the group have changed from the initial "countermeasures" to the "industry statistics", "comparison of Chinese and foreign regulations and policies and experience", "analysis on typical case" and other methods. With the appropriate external conditions, the learning subject has a certain degree of expansive learning will and practice. (2) The experience and demonstration of multi-subject interaction. In the interview, students have mentioned that they are very willing to perform better than other groups in the presence of the experts. It has also observed that students would actively communicate with practical experts and senior graduate students. And the students would submit resume and so on. (3) Individual academic preference, such as academic ascension, vocational qualification preference, employment orientation and professional preference, may exert different level of impact on expansive learning. According to the experiential feedback, it suggests that the expansive teaching experiments and individual academic preferences have an impact on individual expansive learning. And the qualitative 
experimental tips need to be supported with the data developed by the scale.

\section{TO EXPAND THE EVALUATION OF TEACHING EXPERIMENTS}

The ultimate goal of implementing the expansive teaching experiment is to explore the expansive learning theory to change the traditional teaching model of university curriculum in the Chinese situation. And it would explore ways to break through the "authoritative dependence" of Chinese college students. It should seek ways to promote autonomy, cooperation, practice and innovation. The direct purpose is to assess the expansive teaching experiments. Then, it would promote individual extension learning. Therefore, it is necessary to develop an expansive learning scale to measure the willingness and practice of individual experiential learning. And then, it could test whether there are significant differences in the expansive teaching experiments and individual academic preferences.

\section{A. The Measure of Expansive Learning}

\section{1) The measuring dimension of expansive learning}

TABLE I. THE EXPANSIVE LEARNING SCALE OF THE INDIVIDUALS IN EXPANSIVE TEACHING EXPERIMENTS

\begin{tabular}{|c|c|c|c|}
\hline Dimension & Item & Will & Practice \\
\hline \multirow{4}{*}{$\begin{array}{l}\text { Autonomic } \\
\text { Knowledge } \\
\text { Expansion }\end{array}$} & $\begin{array}{l}1.1 \text { The relevant knowledge } \\
\text { outside self-taught classroom and } \\
\text { teaching materials }\end{array}$ & A1_1 & B1_1 \\
\hline & 1.2 To read the related books & A1_2 & B1_2 \\
\hline & $\begin{array}{l}\text { 1.3 To pay attention to the latest } \\
\text { tax policy changes or tax planning } \\
\text { methods }\end{array}$ & A1_3 & B1_3 \\
\hline & $\begin{array}{l}1.4 \text { To pay attention to the } \\
\text { national and industrial knowledge } \\
\text { or economic background, purpose } \\
\text { and impact }\end{array}$ & A1_4 & B1_4 \\
\hline \multirow{4}{*}{$\begin{array}{l}\text { Multi-source } \\
\text { Information } \\
\text { Acquisition }\end{array}$} & $\begin{array}{l}2.1 \text { To obtain information from } \\
\text { the official website of the tax } \\
\text { department }\end{array}$ & A2_1 & B2_1 \\
\hline & $\begin{array}{l}2.2 \text { To obtain information from } \\
\text { paper media such as newspapers } \\
\text { and books }\end{array}$ & A2_2 & B2_2 \\
\hline & $\begin{array}{l}2.3 \text { To obtain information from } \\
\text { the WeChat, microblog, public } \\
\text { accounts and other new media }\end{array}$ & A2_3 & B2_3 \\
\hline & $\begin{array}{l}2.4 \text { To obtain information from } \\
\text { domestic and foreign literature } \\
\text { databases }\end{array}$ & A2_4 & B2_4 \\
\hline \multirow{4}{*}{$\begin{array}{l}\text { Multi-agent } \\
\text { Learning } \\
\text { Interaction }\end{array}$} & $\begin{array}{l}3.1 \text { To exchange tax issues and } \\
\text { learning experience with the } \\
\text { teachers }\end{array}$ & A3_1 & B3_1 \\
\hline & $\begin{array}{l}\text { 3.2 To exchange tax issues and } \\
\text { learning body with the students }\end{array}$ & A3_2 & B3_2 \\
\hline & $\begin{array}{l}3.3 \text { To make report or show their } \\
\text { views or research results in public } \\
\text { areas }\end{array}$ & A3_3 & B3_3 \\
\hline & $\begin{array}{l}3.4 \text { To make discussion on } \\
\text { different points of view }\end{array}$ & A3_4 & B3_4 \\
\hline \multirow{3}{*}{ Practice } & $\begin{array}{l}4.1 \text { To participate in research } \\
\text { projects at all levels of students }\end{array}$ & A4_1 & B4_1 \\
\hline & $\begin{array}{l}4.2 \text { To seek practice opportunities } \\
\text { of tax accountants }\end{array}$ & A4_2 & B4_1 \\
\hline & $\begin{array}{l}\text { 4.3 To seek ways to participate in } \\
\text { the practice of enterprises and } \\
\text { institutions }\end{array}$ & A4_3 & B4_1 \\
\hline
\end{tabular}

In this study, it intends to measure individual expansive learning from four dimensions. (1) In autonomic knowledge expansion: the expansive learning content isn't scheduled knowledge or skills. However, it is the self-construction process of new knowledge. (2) In multi-source information acquisition: the expansive learning has divergence and nonpredetermination. And it could have the acquisition channels of the content in the classroom. Especially, the network and other modern technology have become important ways of learning of contemporary college students. (3) In multi-agent learning interaction: it should establish the expansive learning on the basis of cross-border cooperation. ( $\mathrm{H}$. Kerosuo et al [23]). The learning subject is collectivity or network. The different understandings of the targets and the collision from different individuals could promote selfconstruction and convergent power. (4) In practice: it would show the essence of expansive learning. And the individuals have involved in practice. The interactions between others and the environment could improve the socialization.

It has prepared a total of 27 measurement items through the literature and the discussion. With reference to the evaluation of the scale of three teachers of tax-related courses, a staff of local government tax department and a principal of tax accountants, the topics have been adjusted to 15 items. In order to get more detailed measurement of individual differences on experimental learning, it also measures the willingness and practice of expansive learning in this study. It has shown the scale in "Table I".

\section{2) The quality test of the scale}

In order to avoid the sample loss caused by the passage of time, it put the time of distribution after the end of the course in the first week. And it has commissioned the student union cadres in the name of the student union to make distribution and recovery. The questionnaires are distributed to all students in the experimental and control groups. And it has got a total of 217 valid questionnaires within half of the month.

It has made the evaluation on the quality of the scale with factor analysis. Usually, the number of samples is 5 times as large as that of the scale. The number of samples in this study is 10 times more than the number of items. The KMO coefficients of the willingness and practice scales are greater than 0.8. The Bartlett test has reached to the significance level of 0.01. The MSA coefficient is between 0.7 and 0.9. It suggests that the factor analysis method is suitable for the evaluation of the scale of this experiment.

\section{a) The reliability test}

Students with strong willingness to expand knowledge may be more willing to expand access to get information and interaction. And the students would engage in relevant practice. They could use oblique rotation to deal with factor relationships. The reliability of the two scales is shown in "Table II". 
TABLE II. The ReLIABILITY OF WiLLINGNESS (PRACTICE) SCALE*

\begin{tabular}{|c|c|c|c|c|c|c|}
\hline Dimension & Cronbach $\alpha$ & CR & Item & \begin{tabular}{|c|} 
Corrected Item- \\
Total Correlation
\end{tabular} & $\begin{array}{c}\text { Complex correlation } \\
\text { square } \mathbf{R 2}\end{array}$ & $\begin{array}{c}\text { Cronbach } \alpha \text { if } \\
\text { Item Deleted }\end{array}$ \\
\hline \multirow{4}{*}{$\begin{array}{l}\text { Autonomic } \\
\text { Knowledge } \\
\text { Expansion }\end{array}$} & \multirow{4}{*}{$0.895(0.867)$} & \multirow{4}{*}{$0.892(0.864)$} & 1_1 & $0.692(0.750)$ & $0.492(0.585)$ & $0.892(0.817)$ \\
\hline & & & $1 \_2$ & $0.812(0.665)$ & $0.663(0.467)$ & $0.848(0.852)$ \\
\hline & & & $1 \_3$ & $0.819(0.762)$ & $0.679(0.607)$ & $0.846(0.814)$ \\
\hline & & & $1 \_4$ & $0.764(0.711)$ & $0.606(0.525)$ & $0.868(0.832)$ \\
\hline \multirow{4}{*}{$\begin{array}{l}\text { Multi-source } \\
\text { Information } \\
\text { Acquisition }\end{array}$} & \multirow{4}{*}{$0.868(0.852)$} & \multirow{4}{*}{$0.857(0.863)$} & $2 \_1$ & $0.768(0.732)$ & $0.614(0.587)$ & $0.811(0.795)$ \\
\hline & & & $2 \_2$ & $0.692(0.701)$ & $0.488(0.496)$ & $0.839(0.810)$ \\
\hline & & & $2 \_3$ & $0.739(0.752)$ & $0.582(0.599)$ & $0.824(0.788)$ \\
\hline & & & 244 & $0.683(0.601)$ & $0.475(0.381)$ & $0.843(0.849)$ \\
\hline \multirow{4}{*}{$\begin{array}{l}\text { Multi-agent } \\
\text { Learning } \\
\text { Interaction }\end{array}$} & \multirow{4}{*}{$0.904(0.908)$} & \multirow{4}{*}{$0.911(0.912)$} & $3 \_1$ & $0.828(0.823)$ & $0.712(0.688)$ & $0.861(0.869)$ \\
\hline & & & $3 \_2$ & $0.819(0.777)$ & $0.714(0.640)$ & $0.864(0.888)$ \\
\hline & & & $3 \_3$ & $0.740(0.771)$ & $0.569(0.639)$ & $0.893(0.888)$ \\
\hline & & & 3_4 & $0.784(0.809)$ & $0.624(0.667)$ & $0.884(0.876)$ \\
\hline \multirow{3}{*}{ Practice } & \multirow{3}{*}{$0.930(0.946)$} & \multirow{3}{*}{$0.927(0.942)$} & $4 \_1$ & $0.820(0.835)$ & $0.696(0.714)$ & $0.937(0.943)$ \\
\hline & & & $4 \_2$ & $0.917(0.950)$ & $0.841(0.918)$ & $0.849(0.875)$ \\
\hline & & & 4_3 & $0.863(0.921)$ & $0.779(0.899)$ & $0.895(0.901)$ \\
\hline
\end{tabular}

a. *The data outside the parentheses are the reliability of the scale of willingness. The things inside brackets are the reliability of practice scale.

In "Table II", the index of Cronbach $\alpha$ and the construct reliability (CR) of the four dimensions of the intention and practice scale are above 0.8 . It reflects the high internal consistency of the dimension and the ideal quality of the model. The corrected item-total correlation and complex correlation square R2 of the two scales are close to 1 . And B1_1, A2_2, A2_4 of the willingness scale and B22, B2_2, B2_4 of the practice scale haven't reached to 0.5. However, deleting these items doesn't help improving the total
Cronbach $\alpha$. Therefore, it has retained all the items. And the total index of Cronbach $\alpha$ in the two scales is 0.919 and 0.921. It has reflected the overall reliability of the two scales.

b) The validity measurement

The validity reflects whether the scale can measure the true characteristics of the test content. It generally uses AVE to assess scale validity. It has shown the validity of the two scales in "Table III".

TABLE III. AVE OF WillingNESS (PRACTICE) SCALE*

\begin{tabular}{|c|c|c|c|c|c|}
\hline $\mathbf{F}$ & AVE & item & Esti. & S.E. & $\mathbf{t}$ \\
\hline \multirow{4}{*}{$\begin{array}{l}\text { Autonomic } \\
\text { Knowledge } \\
\text { Expansion }\end{array}$} & \multirow{4}{*}{$0.676(0.616)$} & 1_4 & $0.824(0.777)$ & - & - \\
\hline & & $1 \_3$ & $0.910(0.903)$ & $0.064(0.099)$ & $15.563^{* * *}\left(13.242^{* * *}\right)$ \\
\hline & & $1 \_2$ & $0.838(0.676)$ & $0.071(0.081)$ & $14.417^{* * * *}\left(9.302^{* * *}\right)$ \\
\hline & & 1_1 & $0.703(0.767)$ & $0.062(0.082)$ & $11.174^{* * * *}\left(11.626^{* * *}\right)$ \\
\hline \multirow{4}{*}{$\begin{array}{c}\text { Multi-source } \\
\text { Information } \\
\text { Acquisition }\end{array}$} & \multirow{4}{*}{$0.603(0.619)$} & $2 \_4$ & $0.671(0.596)$ & - & - \\
\hline & & $2 \_3$ & $0.881(0.934)$ & $0.150(0.221)$ & $10.365^{* * *}\left(8.506^{* * *}\right)$ \\
\hline & & $2 \_2$ & $0.683(0.798)$ & $0.099(0.156)$ & $10.575^{* * *}\left(8.425^{* * *}\right)$ \\
\hline & & $2 \_1$ & $0.849(0.782)$ & $0.118(0.157)$ & $10.618^{* * *}\left(8.856^{* * * *}\right)$ \\
\hline \multirow{4}{*}{$\begin{array}{c}\text { Multi-agent } \\
\text { Learning } \\
\text { Interaction }\end{array}$} & \multirow{4}{*}{$0.719(0.722)$} & 3_4 & $0.794(0.867)$ & - & - \\
\hline & & $3 \_3$ & $0.788(0.864)$ & $0.094(0.064)$ & $13.427^{* * * *}\left(15.799^{* * *}\right)$ \\
\hline & & $3 \_2$ & $0.930(0.827)$ & $0.100(0.081)$ & $15.328^{* * *}\left(14.041^{* * *}\right)$ \\
\hline & & $3 \_1$ & $0.873(0.839)$ & $0.100(0.074)$ & $14.670^{* * *}\left(15.093^{* * *}\right)$ \\
\hline \multirow{3}{*}{ Practice } & \multirow{3}{*}{$0.809(0.844)$} & 4_3 & $0.901(0.958)$ & - & - \\
\hline & & 4_2 & $0.947(0.945)$ & $0.045(0.026)$ & $21.044^{* * * *}\left(36.356^{* * *}\right)$ \\
\hline & & $4 \_1$ & $0.848(0.850)$ & $0.041(0.033)$ & $18.209^{* * * *}\left(21.079^{* * * *}\right)$ \\
\hline
\end{tabular}

In "Table III", it shows that the average variance extraction of the two scales is above $0.6 \%$. It exceeds the critical standard of 0.5. And it reflects the good convergence efficiency. The normalized parameter of the two scales is between 0.6 and 0.95 . The index of $t$ has reached to 0.01 . The index of standard error is between 0.041 and 0.221 . The path coefficient is very significant. And there is no significant error. In addition, the variance cumulative rate of the two scales exceeds $75 \%$. The pattern matrix and the structure matrix also suggest that the scale validity and the discriminant validity are ideal. The orthogonal axis method is used and the results are robust. CMIN / DF, GFI, CFI, NFI, b. * The things outside brackets are the willingness scale. The things inside brackets are the practice scale.

c. $* * *$ indicates that the bilateral test is significant at the level of 0.001

RMSEA and other indicators also show that the scale has a good sample fit. ${ }^{1}$

\section{B. To Expand the Effectiveness of Teaching Experiments}

1) variables: It can standardize the willingness and practice scores of individual expansive learning with total factor as a measure. In order to eliminate the influence of students' high self-evaluation, it set binary variables of the expansion of teaching experiment and academic preference factors. The variables are described in "Table IV".

1 The extra data not presented in the text can be obtained from the authors by email. 
TABLE IV. THE VARIABLES DESCRIPTION

\begin{tabular}{|c|c|c|}
\hline Variable & Types & Meaning \\
\hline $\begin{array}{l}\text { The expansive } \\
\text { learning } \\
\text { willingness }\end{array}$ & $\begin{array}{l}\text { Continuous } \\
\text { variable }\end{array}$ & $\begin{array}{l}\text { The total score of the standardized factor of } \\
\text { the expansive learning willingness }\end{array}$ \\
\hline $\begin{array}{c}\text { Expansive } \\
\text { learning practice }\end{array}$ & $\begin{array}{c}\text { Continuous } \\
\text { variable }\end{array}$ & $\begin{array}{l}\text { The total score of the standardized factor of } \\
\text { the expansive learning practice }\end{array}$ \\
\hline $\begin{array}{l}\text { Expansive } \\
\text { teaching } \\
\text { experiment }\end{array}$ & $\begin{array}{l}\text { Virtual } \\
\text { variable }\end{array}$ & $\begin{array}{l}\text { The experimental group would take } 1 \text {, and } \\
\text { the control group would take } 0\end{array}$ \\
\hline $\begin{array}{l}\text { Professional } \\
\text { preference }\end{array}$ & $\begin{array}{l}\text { Virtual } \\
\text { variable }\end{array}$ & $\begin{array}{l}\text { Compared to other professions, it should } \\
\text { take } 1 \text { if the student's preference for his } \\
\text { own profession is more than the average. }\end{array}$ \\
\hline Employment & $\begin{array}{c}\text { Virtual } \\
\text { variable }\end{array}$ & $\begin{array}{l}\text { Compared to other professions, it should } \\
\text { take } 1 \text { if the student's preference for } \\
\text { employment of his own profession is more } \\
\text { than the average. }\end{array}$ \\
\hline $\begin{array}{l}\text { Assessment } \\
\text { method }\end{array}$ & $\begin{array}{l}\text { Virtual } \\
\text { variable }\end{array}$ & $\begin{array}{l}\text { Compared to the non-examination courses, } \\
\text { it should take } 1 \text { if a student spends more } \\
\text { than the average energy in the examination } \\
\text { class. }\end{array}$ \\
\hline $\begin{array}{c}\text { The } \\
\begin{array}{c}\text { enhancement of } \\
\text { education }\end{array} \\
\end{array}$ & $\begin{array}{l}\text { Virtual } \\
\text { variable }\end{array}$ & $\begin{array}{l}\text { It should take } 1 \text { if a student takes part in the } \\
\text { postgraduate entrance exams. }\end{array}$ \\
\hline $\begin{array}{l}\text { Certificate } \\
\text { preference }\end{array}$ & $\begin{array}{c}\text { Virtual } \\
\text { variable }\end{array}$ & $\begin{array}{l}\text { It should take } 1 \text { if a student participates in } \\
\text { various types of certificate examination. }\end{array}$ \\
\hline
\end{tabular}

2) Test results: It uses t test to measure the individual expansion of learning will and practice in the expansive teaching experiments and academic preferences on whether there are significant differences. And the results are shown in "Table V".

Due to the t-test result, the average value of willingness of the students' experiential learning in the experimental group is significantly higher than that of the control group at 0.05. The practical value of the experimental group is significantly higher than that of the control group at the 0.05 level. And the homogeneity test is performed. The results suggest that the expansion of teaching experiments has promoted the expansion of college students' learning.

In the professional preference, the students' preference for the professional development of individual professional willingness and practice are significantly higher than the 0.05 level of students' preference for other professionals. Through the variance homogeneity test, it suggests that the preference of the profession can promote the students to expand the professional learning.

In the employment, the individual's willingness of jobhunting in "his-own" major is higher than in other majors, which passes the t-test in the level of 0.05 . The professional practices of individuals who prefer the professional development in "his-own" major are also higher than those who prefer job-hunting in other majors, which doesn't reach the significant level of 0.1 . The results suggest that the preference for job-hunting in "his-own" major can promote the willingness of college students to expand their learning. However, it can't promote the college student to put the willingness into practice.
TABLE V. THE T-TEST RESULTS

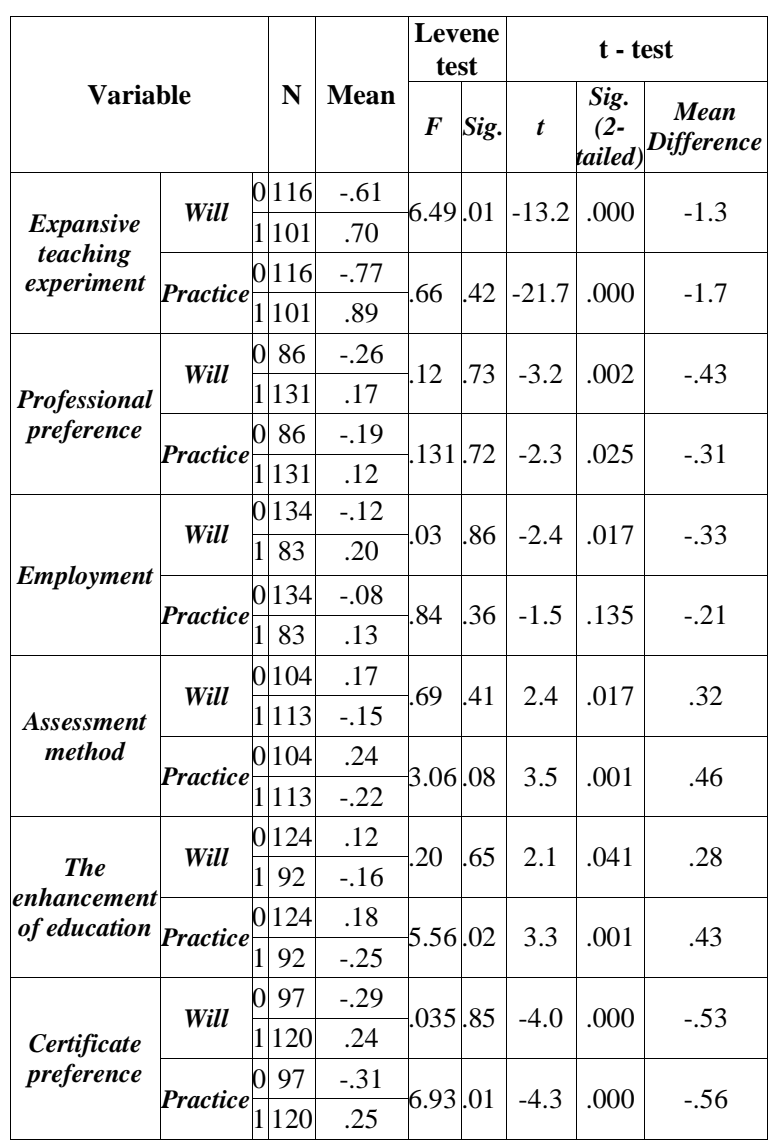

In the assessment, the expansive learning willingness and practice of the students who are more willing to spend more energy in the test class are 0.05 lower than that of the control group. It would suggest that expansive learning willingness and practice of the students who are more willing to spend more energy in the examination course is lower.

For the pursuit of academic qualifications, the level of individual's willingness and practice is significantly lower than that of "satisfying the status quo" at the 0.05 level. The result isn't consistent with the purpose of Chinese graduate education selection and training of innovative talents. In the case of Chinese status, students need to pass the first "threshold" of the national graduate examination. And then, they can enter the university re-examination. And in the first "threshold", it usually makes less assessment of individual knowledge development.

For the professional certification preference, the individual willingness and practice of the students attending various examinations are significantly higher at 0.05 than those who don't participate in any examination. It would suggest that the practitioner's examination may have a significant effect on the expansion of learning. The scope of the examination of certification involves a large number of the knowledge outside the courses. The students need to develop the depth and breadth of knowledge. It has virtually promoted the development of learning.

In addition, the robustness test is performed with the independent samples of Mann-Whitney U and Kolmogorov- 
Smirnov non-parametric tests. The results are consistent with the t-test.

\section{CONCLUSION}

Based on the expansive learning theory, this study has designed the expansion experiment in the university curriculum of China. And it combines the traditional experimental method with the change laboratory. It measures the individual expansive learning from four dimensions of the autonomic knowledge expansion, multi-source information acquisition, multi-agent learning interaction and practice. And then, it explores the learning differences on individual academic preferences of college students. It achieves quantitative assessment of the application of expansive learning base. Firstly, the expansion of teaching experiments has promoted the individual to expand learning. The formative intervention has accelerated the convergence of "best" program of experimental group. And then, it can get good intervention results. The expansive learning theory has good prospect in the field of Chinese university curriculum. Both teachers and college students have participated in learning activities. Instead of "monopolizing", the teachers give guidance to the learning activities. It may break the Chinese students' dependence on teachers' authority. And it can promote autonomy, innovative, cooperative and practical learning. Secondly, the students with more preference for their own majors, educational promotion and professional qualification show significantly higher level of expansive learning. The students who spend more time and energy on close-book exam show significantly lower level of expansive learning. The students with more preference for careers in their own majors show significantly higher level of willingness, but they don't put the will into practice. The conclusion suggests that the constraints can be set in line with individual academic preferences to promote college students' expansive learning.

This study has explored the application model of the expansive learning in the field of Chinese university curriculum. The effectiveness of the application model was tested by developing the expansive learning scale. This study has also tentatively explored the individual difference of expansive learning on the individual academic preference factors. Due to the limited conditions of the experiment, the ascribed status factors such as the characteristics of the family and the social support etc. are not concluded. The future study would expand the experimental field to explore the interaction mechanisms among the teaching methods, expansive learning and individual characteristics.

\section{REFERENCES}

[1] Liu Hua. A new paradigm of classroom teaching: taking the conformity of practice learning activities as the center-Inspiration from American classroom teaching reform [J]. Education Development Research, 2014 (8): 6-12.

[2] J. Biggs \& C. Tang. Teaching for Quality Learning at UniversityWhat the Student Does (3rd edition) [M].Buckingham: SRHE and Open University Press, 2007: 116-123.

[3] Meng Xiangju, Xia Bing. An empirical study on classroom discussion and teaching effect [J]. University Education Science, 2007 (6): 42-44.
[4] Y. Engeström. Expansive Visibilization of Work: An ActivityTheoretical Perspective[J]. Computer Supported Cooperative Work (CSCW), 1999, 8(1-2): 63-93.

[5] Y. Engestrom \& A.Sannino. Studies of expansive learning Foundations, findings and future challenges[J]. Educational Research Review, 2010(5): 1-24.

[6] Wu Gang, Hong Jianzhong, Li Maorong. The conceptual formation in expansive learning-On the basis of the theory of "culture-history" [J]. Modern Distance Education Research, 2014 (5): 34-45.

[7] Wu Gang, Hong Jianzhong. A new learning metaphor: A Study of Expanding Learning - On the basis of the theory of "Culture History" [J]. Journal of Distance Education, 2012, 30 (3): 23-30.

[8] Zeng Wenjie, Liu Xi. Acquisition, participation and knowledge creation-On three metaphors of human learning [J]. Education Research, 2013 (7): 88-97.

[9] Wu Gang. Research on formative intervention in expansive learning [J]. Journal of Distance Education, 2013, 31 (2): 49-56.

[10] J. Virkkunen \& D. Newnham. The Change Laboratory-A Tool for Collaborative Development of Work and Education[M]. Rotterdam: SensePublishers, 2013.

[11] A. Haapasaari, A. Engeström \& H. Kerosuo. The emergence of learners' transformative agency in a Change Laboratory intervention[J]. Journal of Education \& Work, 2016, 29(2):232-262.

[12] Y. Engestrom \& A. Sannino. Whatever happened to process theories of learning? [J].Learning, Culture and Interaction, 2012, (1):45-56.

[13] Y. Engestrom, A. Pasanen, H. Toiviainen \& V. Haavisto. Expansive learning as collaborative concept formation at work[A]. K. Yamazumi, Y. Engestrom \& H. Daniel. New Learning Challenges: Going beyond the Industrial age system and work[C].Osaka: Kansai University Press, 2005, 47-78.

[14] J. Haigh. Expansive learning in the university setting: The case for simulated clinical experience[J]. Nurse Education in Practice.2007(7): 95-102.

[15] M. Gustavsson. Facilitating expansive learning in a public sector organization [J].Studies in Continuing Education.2009, 31(3):245-259.

[16] Y. Engeström, J.Rantavuori \& H.Kerosuo. Expansive Learning in a Library: Actions, Cycles and Deviations from Instructional Intentions[J]. Vocations and Learning, 2013(6): 81-106.

[17] Wu Gang. Research on formative intervention in expansive learning [J]. Journal of Distance Education, 2013, 31 (2): 49-56.

[18] Ma Xiangyuan, Wu Gang. Innovation Laboratory: A new workplace learning approach in China [J]. Zhejiang Social Sciences, 2016 (8): 82-89.

[19] Zhang Lihua. The expansive learning: community perspective and practical implication of the development of teacher [J]. Journal of Educational Science, 2014 (4): 73-79.

[20] Zhang Baocheng The application of expansive learning theory in the development and integration of teacher professional $[\mathrm{J}]$. Journal of Hubei University of Economics (Humanities and Social Sciences), 2017, 14 (03): 100-101.

[21] G. Anthony, R. Hunter, Z. Thompson. Expansive Learning: Lessons from one Teacher's Learning Journey[J]. ZDM Mathematics Education, 2014,46:279-291.

[22] B. Berry \& F. Hess. Expanded Learning, Expansive Teacher Leadership [J].Phi Delta Kappan. 2013(2):58-61.

[23] H. Kerosuo \& H. Toiviainen. Expansive learning across workplace boundaries[J]. International Journal of Educational Research, 2011, 50(1): $48-54$. 